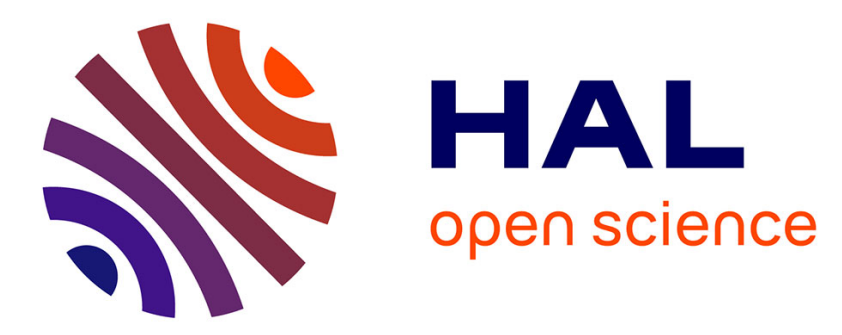

\title{
Landscape change and archaeological settlements in the lower Danube valley and delta from early Neolithic to Chalcolithic time: A review
}

\author{
Jean-Michel Carozza, Christian Micu, Florian Mihail, Laurent Carozza
}

\section{- To cite this version:}

Jean-Michel Carozza, Christian Micu, Florian Mihail, Laurent Carozza. Landscape change and archaeological settlements in the lower Danube valley and delta from early Neolithic to Chalcolithic time: A review. Quaternary International, 2012, 261, pp.21-31. halshs-01064530

\section{HAL Id: halshs-01064530 \\ https://shs.hal.science/halshs-01064530}

Submitted on 16 Sep 2014

HAL is a multi-disciplinary open access archive for the deposit and dissemination of scientific research documents, whether they are published or not. The documents may come from teaching and research institutions in France or abroad, or from public or private research centers.
L'archive ouverte pluridisciplinaire HAL, est destinée au dépôt et à la diffusion de documents scientifiques de niveau recherche, publiés ou non, émanant des établissements d'enseignement et de recherche français ou étrangers, des laboratoires publics ou privés. 


\title{
Landscape change and archaeological settlements in the lower Danube valley and delta from early Neolithic to Chalcolithic time: A review
}

\author{
Jean-Michel Carozza ${ }^{\mathrm{a}, \mathrm{b}, *}$, Christian Micu ${ }^{\mathrm{c}}$, Florian Mihail ${ }^{\mathrm{c}}$, Laurent Carozza ${ }^{\mathrm{b}}$ \\ a Department of Geography, University of Strasbourg, 3 rue de l'Argonne, 67000 Strasbourg, France \\ ${ }^{\mathrm{b}}$ GEODE, UMR 5602 CNRS, Maison de la Recherche, 5 allées A. Machado, 31058 Toulouse, cedex, France \\ ${ }^{\mathrm{c}}$ Intitutul Cercetari Eco-Muzeale-str. Gloriei, Parcul Monumentul Independentei, 820009 Tulcea, Romania
}

\section{A R T I C L E I N F O}

Article history:

Available online 16 August 2010

\begin{abstract}
A B S T R A C T
Palaeogeographic changes of the North Black Sea area during Early to Middle Holocene (i.e. 12-4 ka BP) is of crucial interest in the understanding of the spread of the Neolithic to central and western Europe. It is also a good method to develop a framework for Pre- and Proto-historic societal adaptation to environmental changes. This paper describes Black Sea coastal geomorphological changes associated with sea level rise, delta progradation and delta lobe shifts modifying the living conditions and habitability in the Danube delta during Neolithic to Chalcolithic time. An archaeological and palaeoenvironmental chronological framework allows comparison between environmental and social data. The rhythms of these changes are discussed in the light of spatial changes in settlements. The Neolithic to Chalcolithic transition (i.e. Hamangia, Boian and Gumelnița) shows rapid adaptation to geographical conditions. The Early Neolithic gap in the Dobroudja is potentially the result of a taphonomic bias related to coastal position change in a context of a rapid flooding event.
\end{abstract}

(c) 2010 Elsevier Ltd and INQUA. All rights reserved.

\section{Introduction}

Pre- and Proto-historic societies are highly sensitive to environmental changes from diverse origins: climatic, biogeographic or palaeogeographic. These changes are potential causes of social and territorial reorganisation.

In the case of coastal environments, in particular large deltas, the natural dynamics of these areas are related with rapid changes and landscape transformation. Such rapid changes are often reported for the Lateglacial to Early Holocene time. Palaeogeographical changes are controlled by both progradation and erosion processes on alluvial lobes at the delta scale. These processes are in turn controlled by eustatic and climatic factors. Within each lobe, lateral shifting of distributary channels and associated alluvial body geometry is the main factor of evolution. Landscape transformations acted at a rapid time scale and modified the territory of Pre- and Proto-historic societies.

Our ignorance about resources associated with deltaic spaces is pointed out in Bailey and Flemming (2008). More specifically, the lack of knowledge of ancient human settlements is caused by taphonomical bias in relation with natural and anthropic erosion,

\footnotetext{
* Corresponding author. Department of Geography, University of Strasbourg, 3 rue de l'Argonne, 67000 Strasbourg, France. Tel.: +33 368850922.

E-mail address: carozza@unistra.fr (J.-M. Carozza).
}

alluvial blurring, and submerged sites in the coastal zone (Draganov, 1995; Shilik, 1997). All these factors contribute to create "false" void spaces, quite often perceived as repulsive for ancient societies.

This explanation seems more realistic than the interpretation proposed before. Deltaic areas constituted the core of the development of many Mediterranean civilisations, such as the Nile delta (Allen et al., 1993; Goodfriend and Stanley, 1999), the Rhône delta (Arnaud-Fassetta et al., 2000), and the Pô delta (Stefani and Vincenzi, 2002).

Pre- and Proto-historic societies thus had to develop specific strategies of habitability adapted to strongly mobile spaces. Such adaptation strategies can be either technical (e.g. building), economical (specialisation in resource exploitation) or territorial. Territorial strategies are based on site location choice and complementarity in landscapes and land uses. This type of adaptation is highly dependent on the regularity in the landscape evolution such as described in the Mediterranean Basin during the Holocene (Stanley and Warne, 1994; Vella et al., 2005).

The case of the deltas of marginal Mediterranean Seas (Sea of Marmara, Black Sea, Azov Sea and partly the Caspian Sea) is peculiar. In contrast to the rest of the Mediterranean area whose evolution was under eustatic control during Late- and Post-Glacial (Lambeck and Bard, 2000; Pirazzolli, 2003), Eastern marginal Seas have experimented a complex evolution, due to their total or partial isolation from the Mediterranean through the Bosphorus, 
Dardanelles and Kerch straits and Manych pass. They show a succession of alternating lacustrine and marine phases at least until about $\sim 9400$ cal BP (Lericolais et al., 2007) in relation with hydro-climatic variability.

During low sea level stages, the disjunction of the Marmara Sea to the World Ocean causes the isolation of the Black Sea-Azov Sea system. Climate controls the fluvial runoff to the closed basin and the "lake" level (Major et al., 2002). During global high stands, reconnection with the global ocean causes the Black Sea to evolve under eustatic control.

From an archaeological perspective, the timing and rapidity of the flooding events are a critical issue. In particular, the way the Mediterranean-Black Sea reconnected around $\sim 7400$ bce (Ryan et al., 2003) and its potential effects on the settlement of the littoral and deltaic zones have to be questioned.

In the case of the Black Sea, the hypothesis of a rapid flooding around $\sim 7400$ bce is still a controversial topic (Ryan et al., 1997; Görür et al., 2001; Hiscott et al., 2007; Yanko-Hombach, 2007 and review within; Lericolais et al., 2009). Scenarios proposed by Major (2006) and Lericolais et al. (2009) rest on imprecise radiocarbon dating related to the hardwater effect discussed by Fontugne et al. (2009). They diverge, however, on the timing of the final Black Sea water flooding. Both are compatible with the archaeological data discussed in this paper. However, data from Lericolais et al. (2009) strengthen the hypothesis of a Black Sea flooding around 7400 bce.

The potential consequences of such rapid flooding on archaeological settlements were proposed from a theoretical point of view but very few data support these analysis (Bailey, 2007; Turney and Brown, 2007; Dolukhanov and Arslanov, 2009; Peev, 2009). The consequences of palaeogeographical changes on archaeological settlement during Post-glacial time have to be studied at a regional scale to allow comparison between palaeoenvironmental and archaeological data without a priori on possible co-evolution between natural and social systems.
Instead, construction of a common numerical ${ }^{14} \mathrm{C}$-based chronological framework that allows analysis of the raw data is a priority. This work presents a synthetic new insight into a numerical radiocarbon chronology of the Late Neolithic to Middle Chalcolithic of the Dobroudja region. Consequently, spatial dynamics of the settlement network can be discussed and compared to palaeogeographical evolution of the Danube delta. Archaeological-calibrated data allow consolidation of the chronology of the palaeogeographical evolution of the Romanian Danube delta.

From a geographical point of view, the Dobroudja constitutes the eastern part of the Balkan space (Fig. 1). It ensures the link between the central-European plains with the Euxinian area through the Danubian corridor. The Danubian plain and delta is a key zone in understanding the socio-cultural organization of Preand Proto-historic societies.

In the western part of the Dobroudja, the Danube flows to the north and, above Hirşova, develops a large alluvial plain (Braila Island). This area remained separated from the littoral fringe by the Dobroudjan Mountains. They correspond to the Paleozoic basement high, which limits the loessic plains to the west. Around Galati, the Danube watercourse inflects towards the east to Tulcea. The Danube delta is the junction between these two areas and is the central element of the littoral. Thus, the Danubian corridor appears as an axis ensuring the penetration of the Eastern Balkan influences into the Western Dobroudja and beyond, to the centralEuropean area. Because of this position, it has been able to play a key function in the sprawling of the Neolithic cultures towards the west.

\section{Chronology of Neolithic and Chalcolithic settlements of the Lower Danube area}

The framework of the Neolithic settlement of the lower Danube area is a question directly related with the neolithisation process of

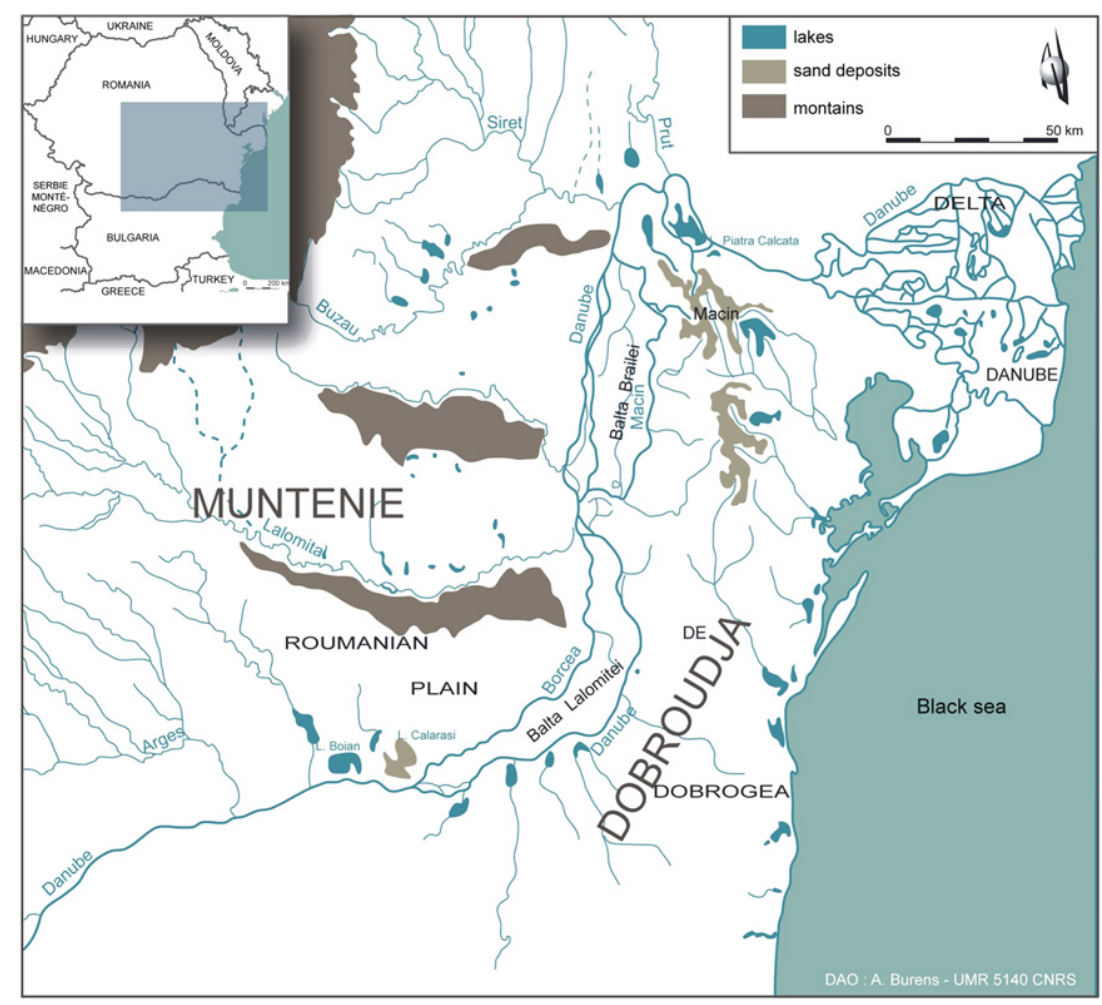

Fig. 1. Location of the study area. 
the Balkan Peninsula. The details of this process and the emergence of Chalcolithic around the Black Sea area cannot be tackled in this short paper. However, the construction of a radiocarbon chronology based on existing data highlights the specific chronological and chrono-cultural problems of the study area.

\subsection{Chronology}

In the north part of the Dobroudja province, the principal archaeological data are dated from Chalcolithic time. The modalities of Early Neolithic settlement process in Dobroudja around $\sim 6000$ bce are largely unknown (Fig. 2). Neolithisation spread in this area has been analysed from an archaeological point of view without integrating palaeoenvironmental and pluridisciplinary data.

Everything leads to the belief that the Neolithisation process in the Lower Danube area is synchronous with the first traces of Neolithic in the central to northern Balkan area around $\sim 6000$ bce (Fig. 3). If the assumption of a diffusive process from northwest Anatolia to the hinterland is correct, the Romanian Black Sea coast could have been subject to an important chronological shift. An alternative hypothesis based on a key-role of coastal navigation and human colonisation of the coastal zone should also be considered. Rising of Black Sea level and the flooding of more than $200 \mathrm{~km}$ of the continental platform could have masked the signs of the oldest settlement of this zone of Balkans during the end of the 7th millennium and the beginning of the 6th millennium. These two assumptions have to be discussed in the light of tangible archaeological and palaeogeographical data.

An exhaustive review of archaeological publications enables construction of a database comprising 35 radiocarbon data for the Neolithic-Chalcolithic period. All the raw data were recalibrated using OxCal v4.1 (Bronk Ransey, 2009). In the first step, all data were taken into account. The oldest have a large standard deviation and were excluded from the final datasheet. Dates whose standard deviation was higher than 100 years, that is to say 650 years in calibrated chronology, were also excluded. The final analysis involved only 11 radiocarbon data satisfying these criteria.

\subsubsection{From Neolithic to Chalcolithic time}

Cultural sequence and material data related to the first population of the Dobroudja start at Late-Neolithic time (Figs. 2 and 4), i.e. at the end of the 6 th millennium and at the beginning of the 5th millennium bce (respectively Boian-Giulesti, Boian-Vidra, Hamangia I and Hamangia II phases). Early Chalcolithic culture (BoianSpantov and Hamangia III) was initiated around $\sim 4900-4500$ bce. For the study area no radiocarbon dating is available for the Boian phase. As a result, the chronological fitting is obtained by extrapolating the regional chronology, especially the dating obtained in Casioarele "Ostrovel" (Bem, 2001) in the Romanian Plain. The corpus of 11 radiocarbon dates provides data of very unequal interest. Some show 120 years standard deviation, e.g. are imprecise over more 700 years in calibrated chronology. More than \pm 100 years uncertainty dates were rejected for the analysis. For this period, only $5{ }^{14} \mathrm{C}$ dates of sufficient quality can be taken in consideration (Table 1 ).

The Middle Chalcolithic corresponds in Dobroudja to the rising of Gumelnita-Karanovo VI culture. This cultural complex developed on a vast geographical surface from the Black Sea coastal zone at the east, to central Bulgaria at the west (Kodjadermen-Karonovo VI) and on the sub-Carpatic arc and north of the Thracian region in Greece in the south (Marinescu-Bîlcu et al., 2001). In Dobroudja, this phase is dated from the second half of the 5th millennium (4500-4000 bce).

The Gumelniţa A1 phase chronology refers to two reliable radiocarbon dates in Harsova and Lişcoteanca in the Braila alluvial plain. In the Dobroudja region, the radiocarbon dating obtained in Isaccea "Suhat" is consistent with this chronology. However, the dated sample was taken in a Boian "Giulesti" context. The Gumelnița A2 phase is more evident in southeast Romania and in Bulgaria (Durankulak: $5475 \pm 50,4450-4230$ bce). Seven radiocarbon dates can be used to fit the Romanian sequence (Table 1).

\subsubsection{From Chalcolithic to early Bronze Age}

The end of the Chalcolithic period (Late Chalcolithic) corresponds to the Cernavoda I culture (around 3900-3500 bce). In Harsova, it is dated from 3640 to 3350 bce. This period is strongly influenced by the steppe population from the northern Black Sea

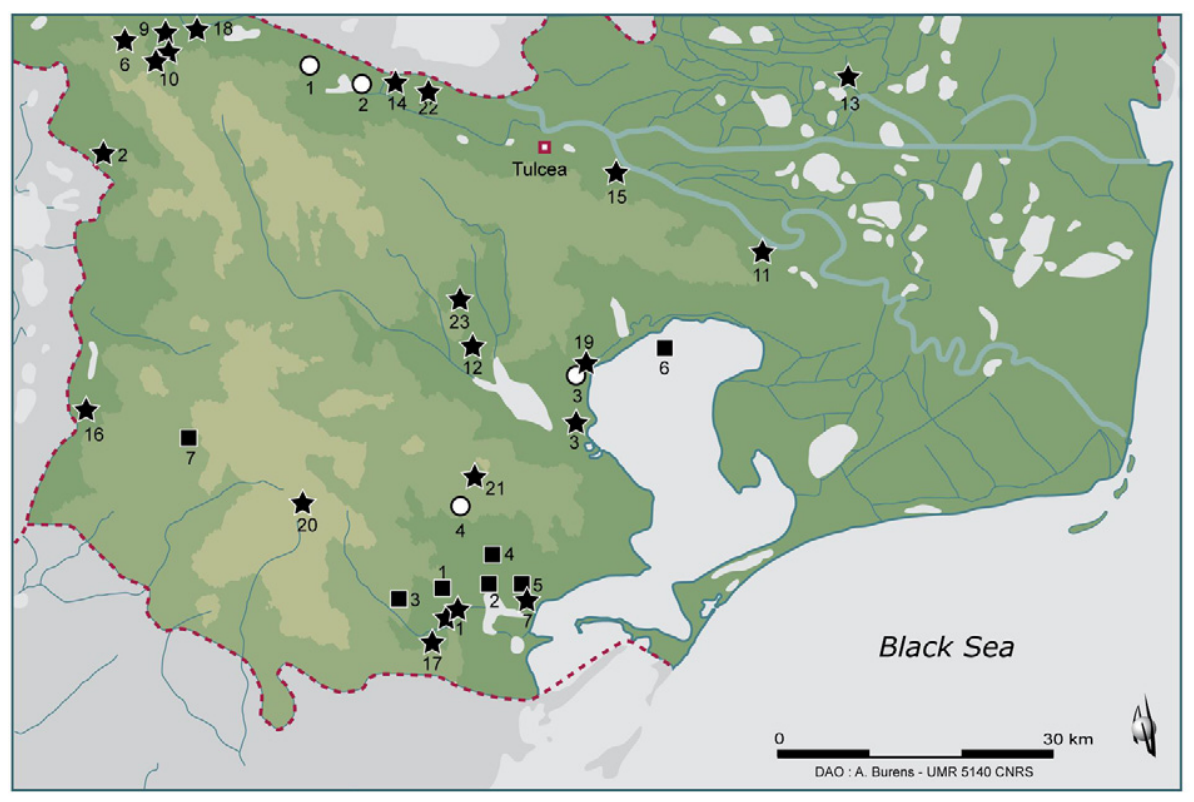

- Hamangia $\quad$ Boian $\quad$ Gumelnita

Fig. 2. Neolithic to Chalcolithic archaeological settlement in the Dobroudja area. 
Early Neolithic

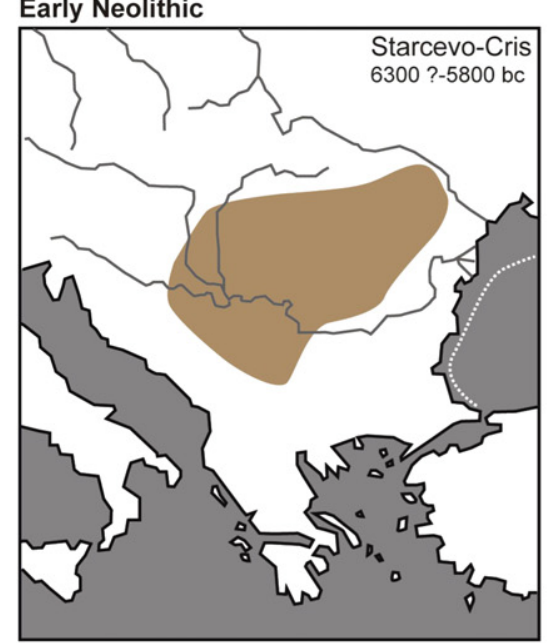

\section{Middle Neolithic}

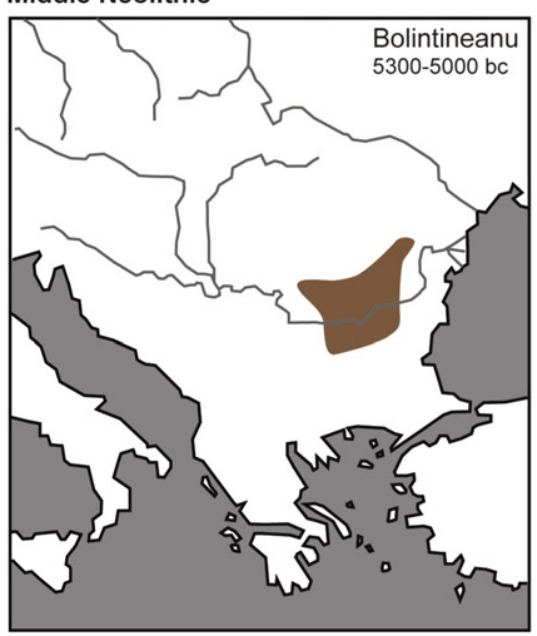

Early Chalcolithic

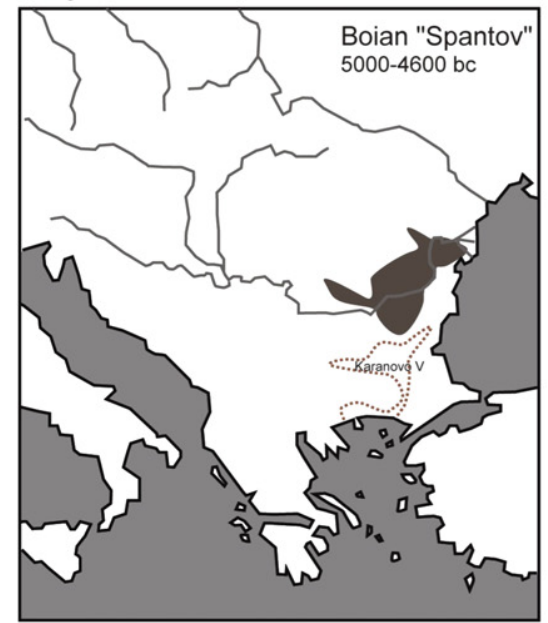

Middle Neolithic

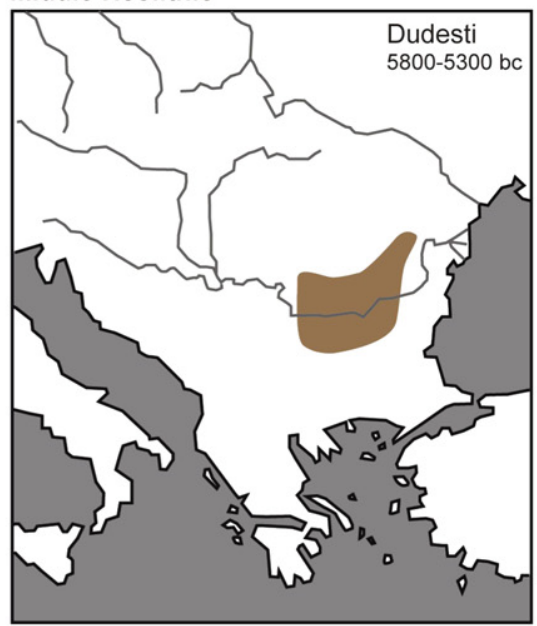

Middle Neolithic -

Early Chalcolithic

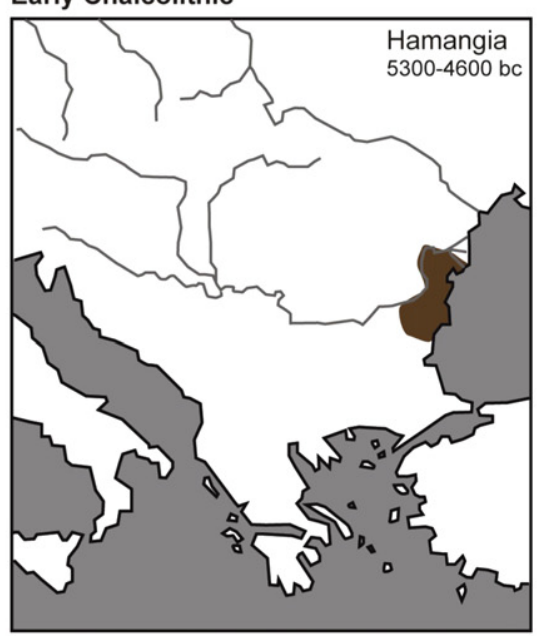

Recent Chalcolithic

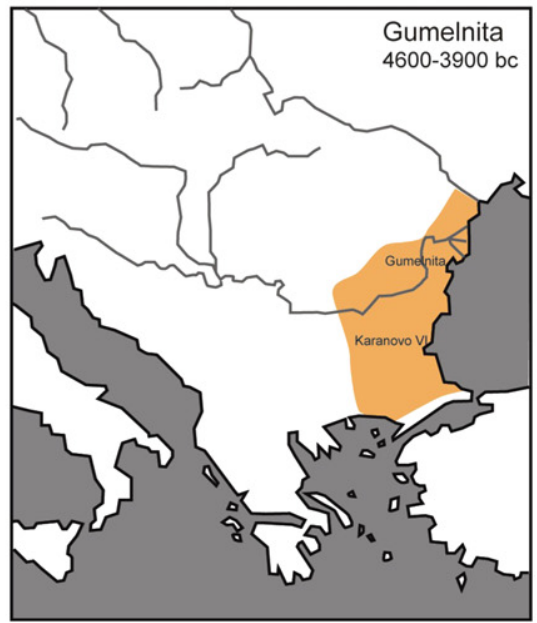

Fig. 3. Spatial and chronological framework of Neolithic/Chalcolithic group in the Balkan area.

area. The beginning of the Early Bronze Age could begin ca. 3500 bce, following a short transition period (Cernavoda III and II, Istoria Românilor, 2001). The interpretation of the transition process to the Bronze Age is of key importance. Whereas the
Cucuteni complex indicates a progressive change, the Chalcolithic group from the Black Sea coast experiences a different process. This latter is characterised by a marked rupture in the material production and settlement pattern. 


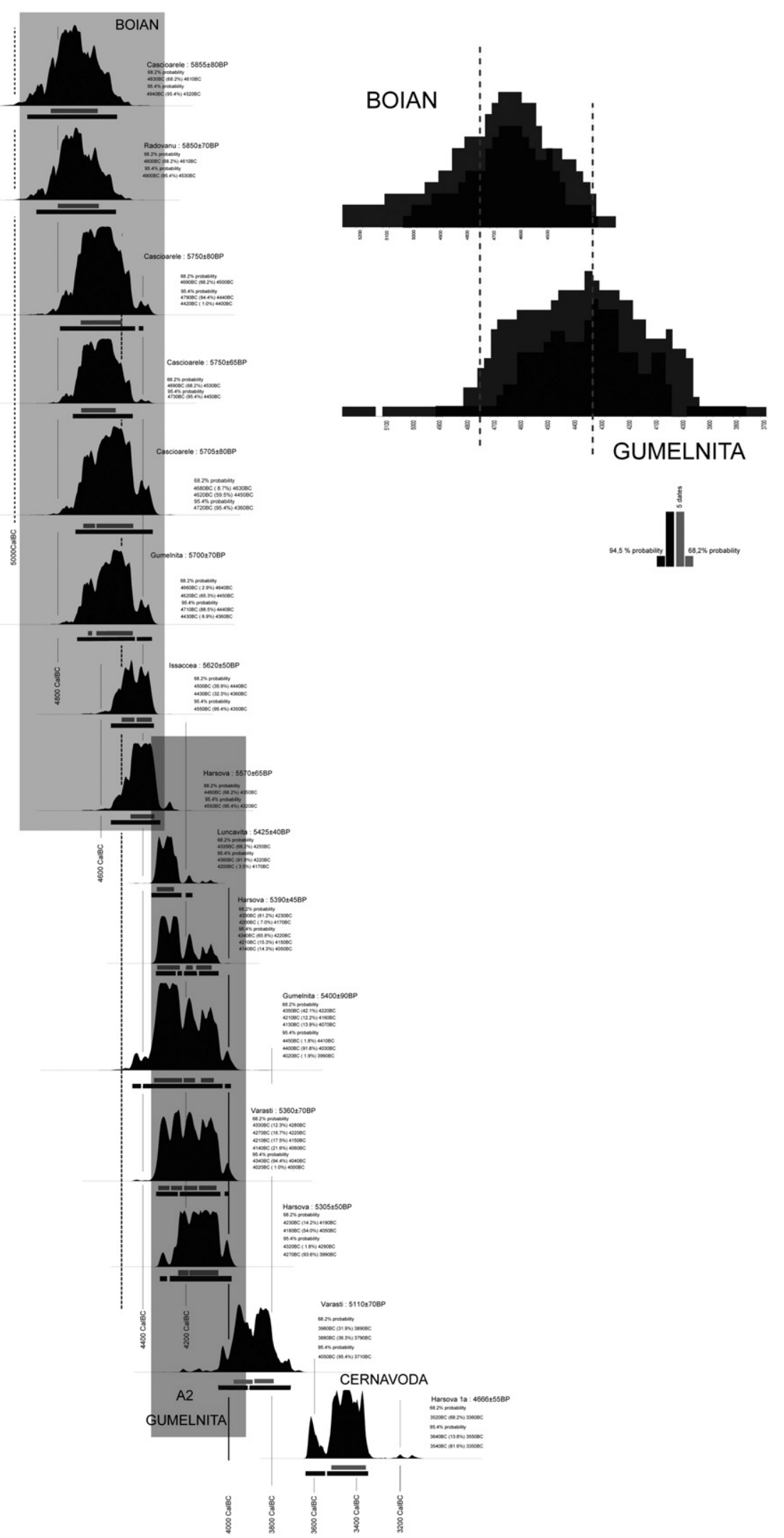

Fig. 4. Radiocarbon chronology of the Eneolithic/Chalcolithic group in Dobroudja. 
Table 1

Availableradiocarbon data for Neolithic/Chalcolithic period in the Dobroudja region.

\begin{tabular}{llll}
\hline Site & Period & Lab dating & $2 \sigma$ calibrated age \\
\hline Casioarele "Ostrovel" & Boian-Spanțov & $5750 \pm 80$ & $4790-4400$ bce \\
Casioarele "Ostrovel" & Boian-Spanţov & $5780 \pm 65$ & $4730-4450$ bce \\
Casioarele "Ostrovel" & Boian-Spanțov & $5705 \pm 80$ & $4720-4360$ bce \\
Casioarele "Ostrovel" & Boian-Spanțov & $5650 \pm 100$ & $4720-4330$ bce \\
Radovanu & Boian-Spanțov & $5850 \pm 70$ & $4900-4530$ bce \\
Harsova & Gumelnita A1 & $5575 \pm 65$ & $4550-4320$ bce \\
Lişcoteanca & Gumelnita A1 & $5640 \pm 50$ & $4590-4350$ bce \\
Isaccea "Suhat" & Gumelnita A1 & $5620 \pm 50$ & $4550-4350$ bce \\
Casioarele "Ostrovel" & Gumelnita A2 & $5675 \pm 100$ & $4730-4330$ bce \\
Gumelnita GrN-3025 & Gumelnita A2 & $5700 \pm 70$ & $4710-4360$ bce \\
Harsova & Gumelnita A2 & $5304 \pm 51$ & $4520-3990$ bce \\
Harsova & Gumelnita A2 & $5380 \pm 45$ & $4340-4050$ bce \\
Varasti & Gumelnita A2 & $5360 \pm 70$ & $4340-4000$ bce \\
Luncavita & Gumelnita A2 & $5425 \pm 40$ & $4360-4170$ bce \\
Varasti & Gumelnita A2 & $5110 \pm 70$ & $4050-3710$ bce \\
Harsova & Cernavoda I & $4665 \pm 55$ & $3640-3350$ bce \\
\hline
\end{tabular}

Radiocarbon data from Bem (2001) except Luncavita (Micu, 2004). New calibration using Oxcal 4.1 (Ramsey, 2001).

\subsection{Settlement pattern}

During Chalcolithic time, the northern Dobroudja attained an unprecedented level of population during the 5th millennium bce (Fig. 2). Whereas only two sites are surely known for the entire Neolithic time, the development of the Gumelniţa culture during Middle Chalcolithic corresponds to a densification in settlements in the Northern Dobroudja, where 26 sites are identified at the present time. A cartographic analysis suggests a link between environmental changes and settlement extension. This idea is supported by the geographical position of the Taraschina site (Mila 23, Tulcea country), within the Danube delta. Previously, the Gumelniţa communities occupied in a privileged way the loess-like terraces of the Danube or its tributaries, promontories, lowlands and lakeshores. This period is also marked by the appearance of a new establishment: the Tells type. The formation of these stratified habitats attests to the permanence of the habitat and a territorial marking founded on the exploitation of vast agrosylvo-pastoral spaces. The development of this kind of establishment marks a major rupture in the social and economic structures. In the Northern Dobroudja, four of the known establishments (Luncaviţa, Ostrov, Baia, Lunca) are located on loess hills of the Danube and its tributaries or in the lowlands near lakes and rivers.

\subsection{A Chalcolithic site within the Danube delta}

The Taraschina site is located within the present day Danube delta, around Mila 23 village (Fig. 5). The site was initially discovered in the 1990s by ICEM researchers. In March 2008, a first surface recognition was carried out. Surface archaeological material sampling has allowed definition of the spatial extent of the site and refinement of the chronological attribution.

The exceptional nature of the Taraschina site is mostly due to its position in the Danube delta. Hitherto, the oldest archaeological occupation in the alluvial context of the Danube delta was attributed to the transition period to Bronze Age (Vasiliu, 1995). Mainly based for the moment on ceramic data (Fig. 6), the Taraschina site is supposed to be Gumelniţa A1 in age, i.e. 4500-4300 bce according to the regional radiocarbon chronology. According to preliminary GPS cartography, the site extends over more than $15000 \mathrm{~m}^{2}$.

Pottery density at the surface, as well as lithic and bony remains and grinding pieces suggest a permanent occupation of the site. This discovery changes in a radical way the representation of the Chalcolithic settlement and territory. Also, it must be taken into consideration for the palaeogeographic reconstitution of the Danube delta evolution during this key period.

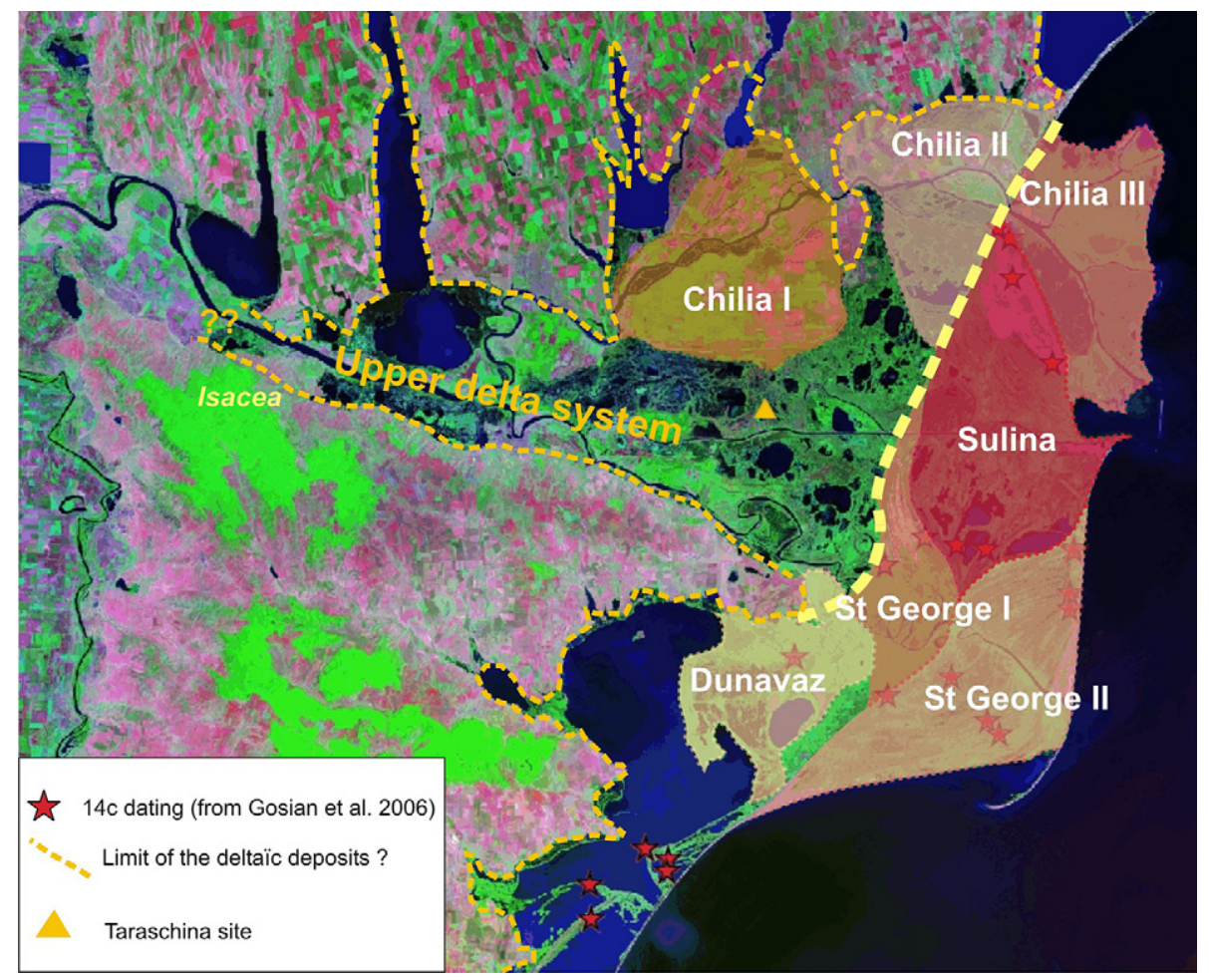

Fig. 5. Danube delta morphology and chronology (adapted and modified from Ghenea and Mihailescu, 1991; Panin, 2004; Giosan et al., 2006). Landsat TM image. 
a
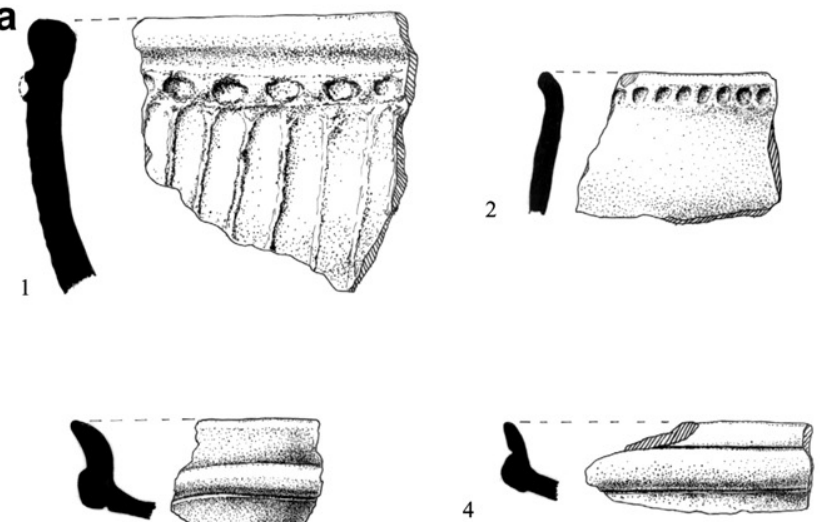

3
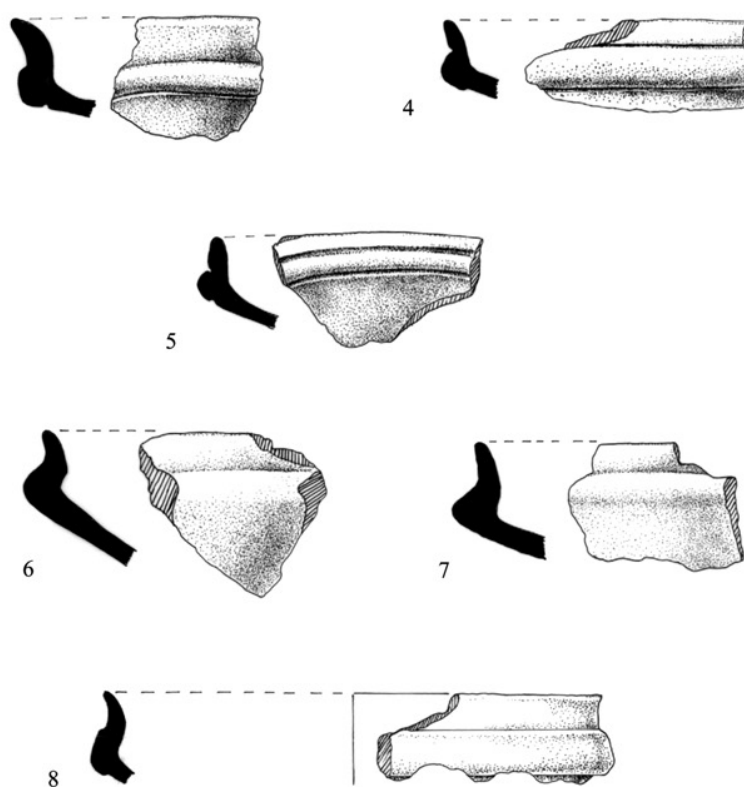
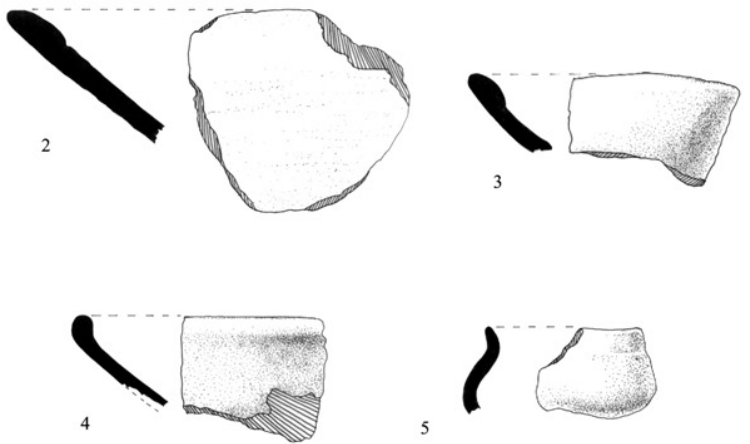

b
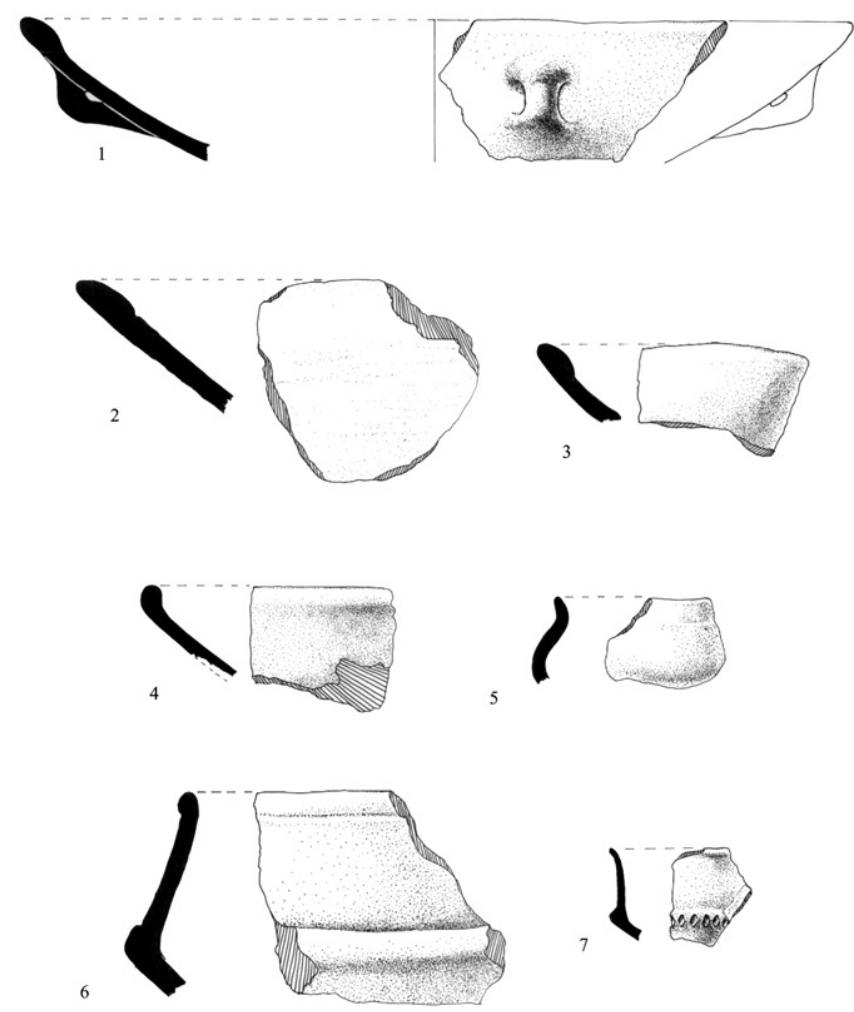

Fig. 6. Gumelnița A1 ceramic from Taraschina site

\section{Danube delta evolution and palaeogeographic framework}

The Holocene evolution of the Danube delta is still a controversial question, in particular for the oldest stages of evolution, i.e. previous to around $\sim 7400$ bce (Panin, 1972, 2004; Ghenea and Mihailescu, 1991; Panin et al., 1983; Giosan et al., 2006, 2009).

The first interpretations of the progradation dynamics were based on geomorphological criteria. Topographic considerations have a key-role in the construction of a relative chronology of the advancing delta. Four main lobes were identified: St Georges I, Sulina, St Georges II and Chilia, in chronological order (Fig. 5). Ghenea and Mihailescu (1991) have proposed to split the Sulina lobe evolution into two phases, Sulina I and Sulina II-Coşna. Later, Romanescu (2005) and Giosan et al. (2006) described new unidentified alluvial bodies. On the south side of the delta, the Dunavatz lobe corresponds to the southern distributary channel of the Danube, reaching into the Razim lagoon. It corresponds to the Coşna lobe. As the radiocarbon dating of these deposits indicates a younger age, it seems justified to separate it from the St Georges I and Sulina II lobes. On the Chilia distributary, two alluvial bodies can be identified on both sides of the Chilia height. On the western part, the Chilia I lobe corresponds to the Pardina lowlands. On the eastern part, the Chilia II lobe occupies it. The precise nature and timing of this lobe construction is still in discussion (Giosan et al., 2005). Panin et al. (1986) have suggested a marine evolution for this area, associated with high sea level during Sub-boreal. Netherless, a fluvial palaeo-network can be recognised by remote sensed image suggesting at least a partial terrestrial evolution. These two alluvial bodies are in an uncommon position compared to the others. They are located above the Letea-Caraorman initial spit, which represents the major sedimentary feature of the delta (Panin, 1972).

The study of alluvial facies and radiocarbon dating of the main alluvial body was initiated by Panin (1972) and Panin et al. (1983). These authors proposed a chronological model covering the whole Holocene time. Prior to $9750-5550$ bce, sedimentation took place in an embayment (blocked delta phase) up to the Letea-Caraorman spit. Later, the progradation of the fluvial lobe of St Georges I initiated the "fluvial dominated" phase of the delta evolution, around $7050-5250$ bce. Attention of scientific research programs mainly focuses on this second phase of rapid alluvial progradation. Panin et al. (1983) have proposed an outline of the evolution for each of the lobes between $\sim 7050$ and 5250 bce to present. St Georges I sedimentation takes place during $\sim 7050-5250$ bce. Next, the distributary channel of Sulina initiated progradation from $\sim 5250$ bce to the 1 st century bce. This lobe experienced a phase of rapid degradation since the Roman period. St Georges II and Chilia deltas are attributed to the last two millennia. The Coşna lobe developed between $\sim 1500$ bce and 500 ad.

The integration of this chronology into the regional chronostratigraphic framework and the Holocene Black Sea evolution is without some problems (Giosan et al., 2006). These authors have proposed a renewed chronology of the deltaic lobe evolution, based on ${ }^{14} \mathrm{C}$ and OSL dating. Three major steps of evolution have been recognised (Fig. 7). The St Georges I lobe would have been active during 3650-1850 bce. The sedimentary activity of the Sulina lobe would have been prolonged from 400 bce to 350 bce. The St Georges II lobe, active since this date to the present would be in the 


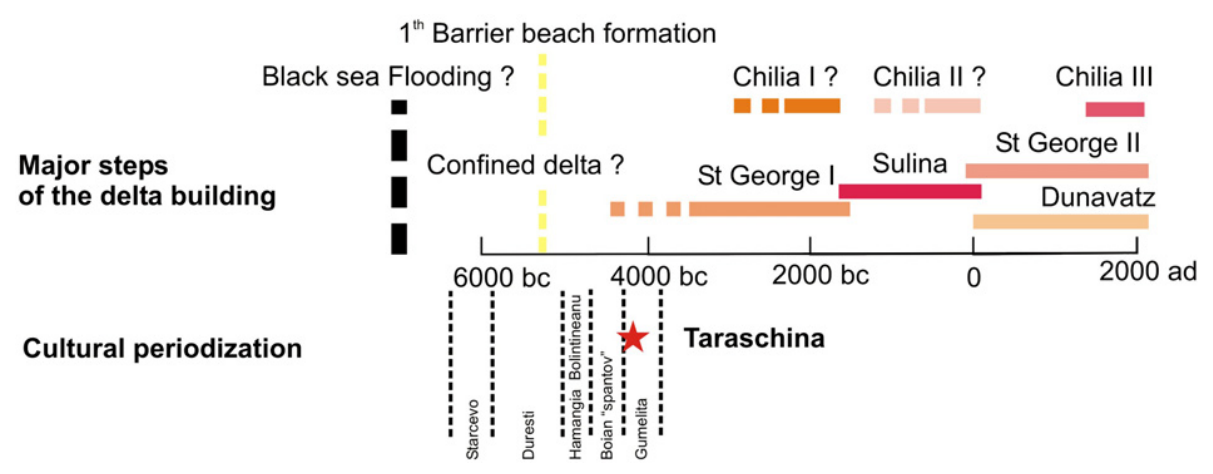

Fig. 7. Synthetic chronology of the Danube delta building phases (adapted and modified from Giosan et al., 2006).

course of abandonment in favour of the Chilia III lobe (Giosan et al., 2005). Very few chronological indications are available to insert the Chilia I and II lobe in this chronology. The Coşna-Dunavatz would be attributed to the first millennium ad. These new chronological insights shortened the evolution of the delta to the second half of the Holocene. Giosan et al. (2006) suggest that marine sea level was stable, as the current level was reached ca. 3200 bce.

Both chronologies proposed by Panin et al. (1983) and Giosan et al. (2006) are rather incompatible. Stanley (2001) reports that dating of alluvial activity in deltaic systems is often problematic. Differences in sampling material and methodology can give considerable variations. For these methodological considerations, the chronology proposed by Giosan et al. (2006) seems more consistent and will be used for the comparison with archaeological chronology.

In this perspective, palaeogeographical evolution of the delta during Neolithic to Chalcolithic (Boian: 5000-4600 bce; Gumelnita A1 and A2: 4600-3900 bce) could be as follows. It seems established that the major spit of Letea-Caraorman is a structure formed very early in the history of the delta, towards $\sim 5200-4800$ bce. It suggests that a relative stable sea level, close to the present day one, was effectively obtained since this period, which is compatible. Correlation with Mediterranean Sea data (Vella et al., 2005) is problematic. The geometric continuity of the

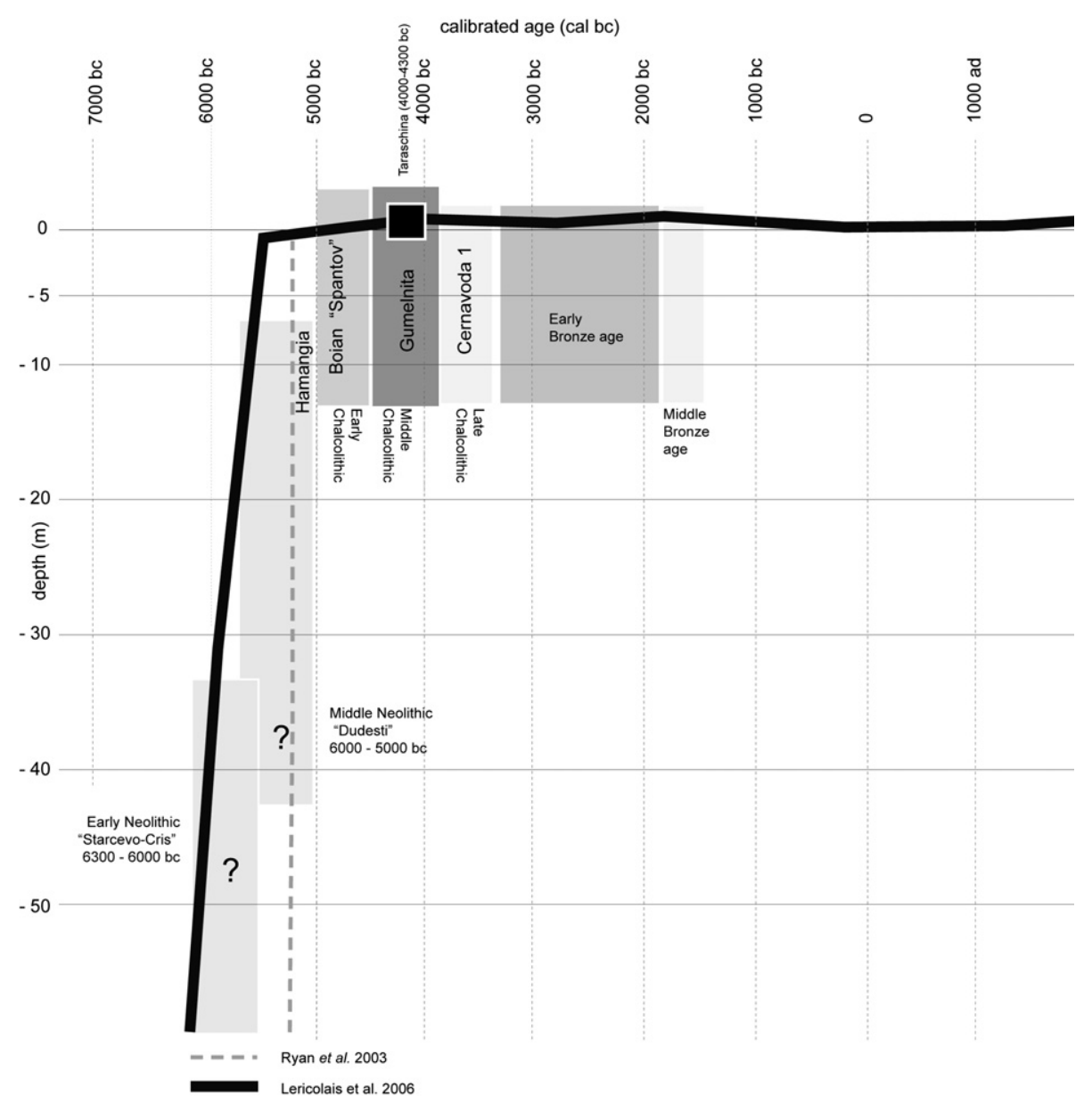

Fig. 8. Relation between cultural chronology of Eneolithic/Chalcolithic and Black Sea sea level, including Taraschina position. 


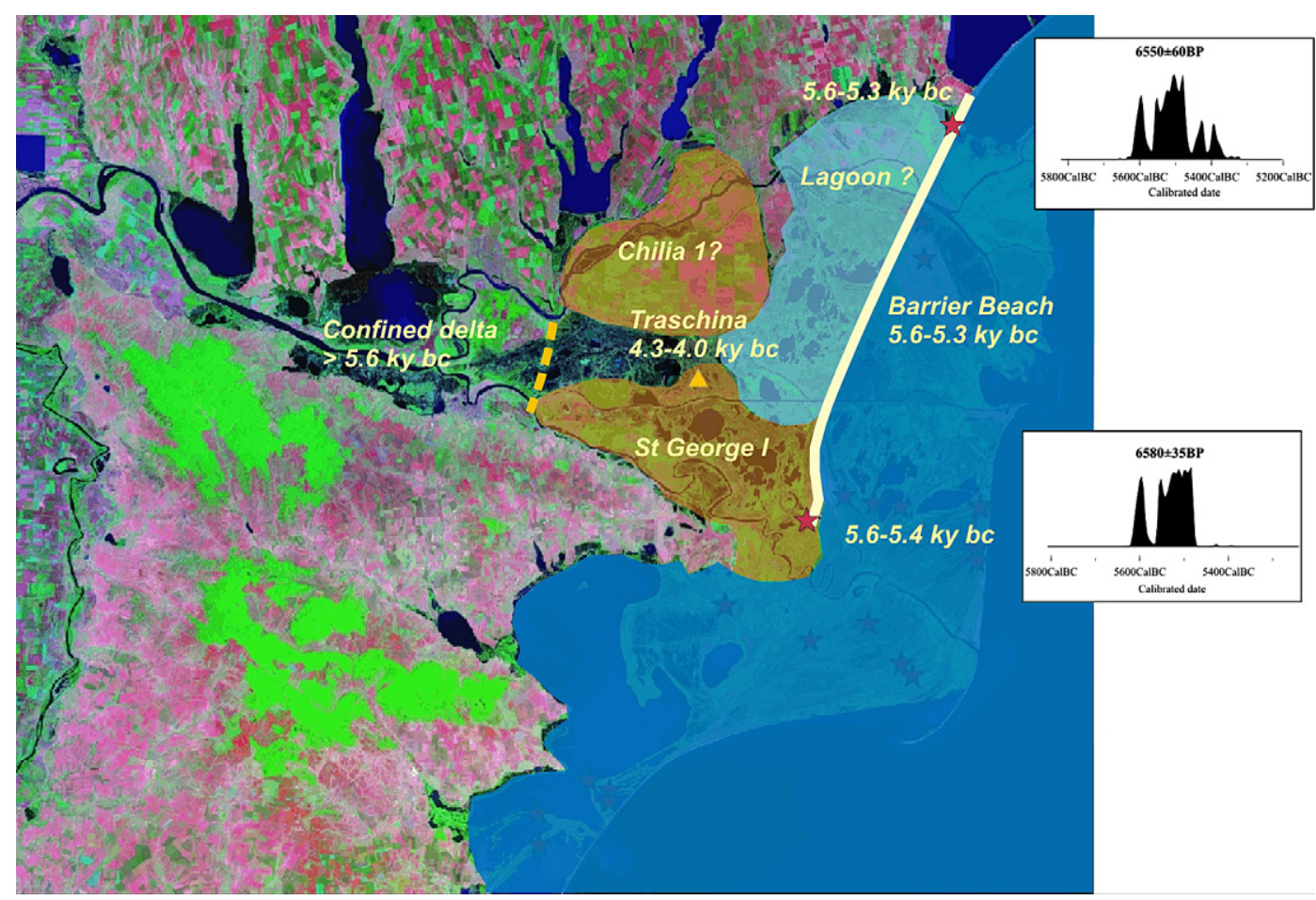

Fig. 9. Position of Taraschina site within palaeogeographical environment of the Danube delta during Eneolithic/Chalcolithic time.

principal Letea-Caraorman spit through the whole delta is confirmed by 2 radiocarbon data in the north (5230-4870 bce) and in the south (5220-4800 bce). It suggests the formation of a continuous beach ridge during the Hamangia period. There are no data to support the edification of a delta lobe during that period. It suggests that the Danube did not yet directly enter the sea but instead emerged in a vast lagoon as described by Ghenea and Mihailescu (1991) on the basis of lithostratigraphic analysis of the boreholes. The area between the Caraorman spit and the raised area of Chilia Veche-Stipoc high corresponds to the Maltita lagoon.

The main tributary of the Danube occupied a southernmost position (proto-St Georges I distributary channel). It is probable that, simultaneously, the lobe of Chilia I constituted a secondary distributary channel, reaching the Pardina depression. The epigenetic position of the Chilia distributary on the raised area of Chilia high could be the result of slope reduction as the delta prograded seaward during stages Chilia II and III. In any case, the deposits of the Tulcea lobe, as defined by Giosan et al. (2009) are older than 4800 bce and a date for termination is given by the Taraschina site ( 4600-3900 bce).

The position of the Taraschina-Mila 23 site has several consequences and implications. At first, the site demonstrates that a sea level close to $0 \mathrm{~m}$ asl has been attained in the delta as early as $4300-4000$ bce (Fig. 8 ). On the other hand, it shows the reactivity of the proto-historic societies that colonised the new areas in a few centuries. The localisation of the site, at the probable junction of firm earth and lagoon spaces suggests a strategic positioning, favourable to the control of the territories ahead as well as of navigation.

\section{Discussion: reactivity and society adaptation to rapid changes}

The synthesis of both archaeological and palaeogeographical data allows consideration from a new point of view of the colonisation scenario of the Romanian Black Sea coast and the lower Danube valley by agro-pastoral communities during the Eneolithic.

No archaeological information makes it possible to characterise the Early Neolithic period. By analogy with the nearby areas, the Neolithisation of the Lower Danube might have occurred between the 7th and of the 6th millennium bce. How can this absence of data can be explained? Perhaps archaeological exploration of the Lower Danube and its delta has failed to identify Early Neolithic occupation. Other factors can also be suggested. A possibility is the hypothesis of certain researchers who assumed neolithisation in the hinterland (Oltenia, Muntenia), thus going up the Danube valley. The authors agree with the proposition of Bolomey (1978) who linked the absence of archaeological data to a taphomic bias related to major and rapid transformation in the palaeogeography of the Lower Danube and delta system during the Holocene (Fig. 8). A schematic reconstitution of the seashore position during Early to Middle Neolithic, as proposed by Dolukhanov and Arslanov (2009) suggest that a large part of the archaeological information is undersea and unattainable. Moreover, in the hypothesis of a key function of the coastal zone in the diffusion of neolithisation as reported in other alluvial coastal plains in Eastern and Western Mediterranean Sea, a great part, even the totality of the archaeological sites, would be submerged nowadays.

The sea level change in Black Sea during the 6th millennium might result in a rise of the marine level of almost 50 ms between $\sim 6000$ and 5500 bce (Lericolais et al., 2007). Such a rapid change can have blocked Neolithic settlement.

Giosan et al. (2006) suggest that the Black Sea level might have been stable since at least 3400 bce. The ASSEMBLAGE curve (in Strechie-Sliwinski, 2007) and Lericolais et al. (2007) suggest that present day, or very close to, sea level, was reached between $\sim 5500$ and 4800 bce. According to this last reconstruction, between $\sim 6000$ and 4800 bce, the Black Sea level was between -10 and $-2 \mathrm{~m}$ asl and rose rapidly to its present value. 
On a regional scale, archaeological data indicate that the coastal zone of Bulgaria was first populated during $\sim 5300-4600$ bce by the Hamangia II and III cultures. The excavated habitats describe agro-pastoral societies which exploited complementary resources of the environment. The importance of predation activities, in particular fishing, hunting and mollusc collection, demonstrate the diversity of the environment exploitation strategies, in particularly in the littoral zones and around the Danube delta.

Mapping of these habitats reveals a "littoralisation process" of the settlement, mainly located on the border of Lake Razim, an open lagoon during the Middle Neolithic (Fig. 9). The settlement distribution also was polarised around the Danubian corridor. Here, the environmental diversity and particularly the complementarities between the loessic terraces, which is of interest for cropping, and lowlands, seems to have played a key-role in the settlements of the Middle Neolithic population.

As pointed out previously, the settlement framework was denser during Early to Middle Chalcolithic time, i.e. $4600-3900$ bce, as the environment stabilised. The settlement fixing appears through the "tell" formation, which implies the succession of wood and clay habitats during several centuries. The stabilisation was accompanied by settlement densification, as attested by the existence of temporary habitats, probably related to specialised activities. The inner complementarily of the settlement reveals as well an increasing pressure on environmental resources. The development of fishing and hunting accompanied the rise of agriculture, as shown by the great diversity of agricultural equipment. In this context, Chalcolithic society experienced a demographic increase and had to colonise unoccupied new lands. The Taraschina settlement could be one of these. This early settlement is directly correlated with the environmental stabilisation. Proto-historic societies are able to react quickly to major transformations and to take advantage of these new environmental potentialities.

\section{Conclusions}

The reconstitution of the palaeogeographic evolution and the timing of the Black sea flooding constitute a challenge in the comprehension of the spreading process of neolithisation to eastern and central Europe. The Danube Lower Delta could have played a key function in this process. The discovery and dating of the site of Taraschina site shows that the Danube delta did not constitute a "no man's land" or a border to the Neolithic diffusion process. It does not constitute a repulsive zone.

The attribution of the Taraschina site to the Gumelniţa period on the basis of chronotypologic analysis remains to be confirmed by radiocarbon dating (in progress). These artifacts were collected at the topsoil surface and probably give a terminal date for the occupation. Moreover, the exact palaeogeography of the site needs to be defined, in particular the nature of the geological substratum to show the potential use of the site as a palaeogeographic and chronotypologic marker in the discussion about the Black Sea flooding chronology.

The presence of a Gumelnița site within the Danube delta, probably located on a ridge between the inner delta and close to a lagoonal area, suggests a large adaptation potential of the Gumelniţa societies to a large range of landscapes. Economic models as well as territorial models have to keep these facts in consideration. Moreover, the short lag time between environmental changes in the delta and the first occurrence of human settlements within the delta indicates the rapid adaptation of the Eneolithic societies to changing environmental conditions. The question about natural influence on societies and determinism has to take this dimension into account.

\section{References}

Allen, R.O., Hamroush, H., Stanley, D.J., 1993. Impact of the environment on Egyptian civilization before the pharaohs. Analytical Chemistry 65, 32A-43A.

Arnaud-Fassetta, G., De Beaulieu, J.-L., Suc, J.-P., Provansal, M., Williamson, D. Leveau, P., Aloisi, J.-C., Oberlin, C., 2000. Evidence for an early land use in the Rhone delta (Mediterranean France) as recorded by late Holocene fluvial Geodinamica Acta 13 (6), 377-389.

Bailey, N.G., 2007. Holocene changes in the level of black Sea: consequences at a human scale. In: Yanko-Hombach, V., Gilbert, A.S., Panin, N., Dolukhanov, P. (Eds.), The Black Sea Flood Question: Changes in Coastline, Climate, and Human Settlement. Springer, Dordrecht, The Netherlands, pp. 515-536.

Bailey, N.G., Flemming, N.C., 2008. Archaeology of the continental shelf: marine resources, submerged landscapes and underwater archaeology. Quaternary Science Reviews 27, 2153-2165.

Bem, C., 2001. Noi propuneri pentru schiţă cronologică a eneoliticului românesc Pontica XXXIII-XXXIV, 25-121.

Bolomey, A., 1978. Why no early Neolithic in Dobrogea? Dacia 22, 5-9.

Bronk Ransey, C., 2009. Bayesian analysis of radiocarbon dates. Radiocarbon 51 (1) 337-360.

Dolukhanov, P.M., Arslanov, K.A., 2009. Ecological crises and early human migrations in the Black Sea area. Quaternary International 197, 35-42.

Draganov, V., 1995. Submerged coastal settlements from the final Eneolithic and the early Bronze Age in the sea around Sozopol and Urdoviza Bay near Kiten. In: Bailey, D.W., Panayotov, I. (Eds.), Prehistoric Bulgaria. Monographs in World Archaeology, 22. Prehistory Press, Madison, Wisconsin, pp. 225-241.

Fontugne M., Guichard F., Bentaleb I., Strechie C., Lericolais G., 2009. Variations in ${ }^{14} \mathrm{C}$ reservoir ages of Black Sea waters and sedimentary organic carbon during anoxic periods: influence of photosynthetic versus chemoautotrophic production. Radiocarbon 51 (3).

Ghenea, C., Mihailescu, N., 1991. Palaeogeography of the lower Danube valley and the Danube delta during the last 15000 years. In: Starkel, L., Gregory, K.J., Thornes, J.B. (Eds.), Temperate Palaeohydrology. Wiley \& Sons, Chichester, pp. $343-363$.

Giosan, L., Donnelly, J.P., Vespremeanu, E., Bhattacharya, J.P., Olariu, C., 2005. River delta morphodynamics: examples from the Danube delta. Rivers Delta concepts, models and examples. SEPM Special Publication 83, 393-411.

Giosan, L., Donnelly, J.P., Constantinescu, S., Filip, F., Ovejanu, I., VespremeanuStroe, A., Vespremeanu, E., Duller, G.A.T., 2006. Young Danube delta document stable Black Sea level since the middle Holocene: morphodynamic, paleogeographic, and archaeological implications. Geology 34, 757-760.

Giosan, L., Filip, F., Constantinescu, S., 2009. Was the black Sea catastrophically flooded in the early Holocene? Quaternary Science Reviews 26, 1-6.

Goodfriend, G.A., Stanley, D.J., 1999. Rapid strand-plain accretion in the northeastern Nile Delta in the ninth century A.D. and the demise of the port of Pelusium. Geology 27, 147-150.

Görür, N., Çăgatay, M.N., Emre, O., Alpar, B., Sakınç, M., Islamoğlu, Y., Algan, O., Erkal, T., Kecer, M., Akkök, R, Karlık, G, 2001. Is the abrupt drowning of the Black Sea shelf at $7150 \mathrm{yr}$ BP a myth? Marine Geology 176, 65-73.

Hiscott, R.N., Aksu, A.E., Mudie, P.J., Marret, F., Abrajano, T., Kaminski, M.A., Evans, J., Cakiroğlu, A.I., Yasar, D., 2007. A gradual drowning of the southwestern Black Sea shelf: evidence for a progressive rather than abrupt Holocene reconnection with the eastern Mediterranean Sea through the Marmara Sea gateway. Quaternary International 167-168, 9-34.

Istoria Românilor, 2001. Moştenirea Timpurilor Îndepărtate, vol. I coordonateurs Acad. Mircea Petrescu-Dîmbovița, Alexandru Vulpe, Bucuresti.

Lambeck, K., Bard, E., 2000. Sea-level change along the French Mediterranean coast for the past 30000 years. Earth and Planetary Science Letters 175, 203-222.

Lericolais, G., Popescu, I., Guichard, F., Popescu, S.M., Manolakakis, L., 2007. Waterlevel fluctuations in the Black Sea since the last glacial maximum. In: YankoHombach, V., Gilbert, A.S., Panin, N., Dolukhanov, P. (Eds.), The Black Sea Flood Question: Changes in Coastline, Climate, and Human Settlement. Springer, Dordrecht, The Netherlands, pp. 437-452.

Lericolais, G., Bulois, C., Gillet, H., Guichard, F., 2009. High frequency sea level fluctuations recorded in the Black Sea since the LGM. Global Planetary Change $66,65-75$.

Major, C.O., 2006. The co-evolution of Black Sea level and composition through the last deglaciation and its paleoclimatic significance. Quaternary Science Reviews 25, 2031-2047.

Major, C., Goldstein, S.L., Ryan, W., Piotrowski, A., Lericolais, G., 2002. Climate change in the Black Sea region through termination $\mathrm{I}$ from $\mathrm{Sr}$ and $\mathrm{O}$ isotopes. Geochimica et Cosmochimica Acta 66 (15A) A476-A476.

Marinescu-Bîlcu, S., Voinea, V., Dumitrescu, S., 2001. Aşezarea neolitică de pe insula “La Ostrov", lacul Taşaul (Năvodari, jud. Constanţa). Raport preliminar. Campaniile 1999-2000. Pontica XXXIII-XXXIV, 123-149. 2000-2001.

Micu, C., 2004. Neo-Eneoliticul in nordul Dobrogei in lumina cercetarilor de la Issaccea si Luncavita. Teza de Doctorat, Institul de Arheologie "Vasile Parvan" Bucaresti. Academia Romana, 250. $292 \mathrm{pl}$.

Panin, N., 1972. Histoire quaternaire du Delta du Danube, Essai d' interpretation des facies des depots deltaiques. Cercetari Marine 4, 5-15.

Panin, N., 2004. The Danube delta. Geomorphology and Holocene evolution: a synthesis. Geomorphologie: Relief, Proceesus, Paysage 9 (4), 247-262.

Panin, N., Panin, S., Herz, N., Noakes, J.E., 1983. Radiocarbon dating of Danube delta deposits. Quaternary Research 19, 249-255. 
Panin, N., Mihailescu, N., Panin, S., Gaita, C., Rogojina, C., Folea, A., Costea, C., Radan, S., Radan, M., Radan, S., Spinoche, S., 1986. Studul Geologic-geofisic Al Deltei Dunarii. Archives of the Institute of Geology and Geophysics, Bucaresti, $240 \mathrm{pp}$.

Peev, P.I , 2009. The Neolithisation of the Eastern Balkan Peninsula and fluctuations of the Black Sea level. Quaternary International 197, 87-92.

Pirazzolli, P.A., 2003. Mid- and late-Holocene relative sea-level changes in the Mediterranean area: a review of selected sites with discussion of the possible eustatic, isostatic and tectonic contributions. In: Coastal Environmental Change during Sea-level Highstands: a Global Synthesis with Implications for Management of Future Coastal Change, pp. 11-12. Puglia 2003-Final Conference Project IGCP 437.

Ramsey, C., 2001. Development of the radiocarbon calibration program OxCal. Radiocarbon 43 (2A), 355-363.

Romanescu, G., 2005. Morpho-hydrographical Evolution of the Danube Delta, II. Terra Nostra Publisher, Iasi, Romania, 296 pp.

Ryan, W.B.F., Pitman III, W.C., Major, C.O., Shimkus, K., Moskalenko, V., Jones, G., Dimitrov, P., Gorur, N., Sakinc, M., Yuce, H., 1997. An abrupt drowning of the Black Sea shelf. Marine Geology 138, 119-126.

Ryan, W.B.F., Major, C.O., Lericolais, G., Goldstein, S.L., 2003. Catastrophic flooding of the Black Sea. Annual Review of Earth and Planetary Sciences 31, 525-554.

Shilik, K.K., 1997. Oscillations of the Black Sea and ancient landscapes. Colloquia Pontica 3, 115-130.
Stanley, D.J., 2001. Dating modern deltas: progress, problems, and prognostics. Annual Review Earth Science 29, 257-294.

Stanley, D.J., Warne, A.G., 1994. Worldwide initiation of Holocene marine deltas by deceleration of sea-level rise. Science 265 (5169), 228-231.

Stefani, M., Vincenzi, S., 2002. The interplay of eustasy, climate and human activity in the late quaternary depositional evolution and sedimentary architecture of the Po Delta system. Marine Geology 222-223, 19-28.

Strechie-Sliwinski, C., 2007. Changements environnementaux récents dans la zone du Nord-Ouest de la Mer Noire. GeoEcoMarina 13 (1), 1. 270.

Turney, C.S.M., Brown, H., 2007. Catastrophic early Holocene sea level rise, human migration and the Neolithic transition in Europe. Quaternary Science Reviews 26, 2036-2041.

Vasiliu, I., 1995. Cercetări arheologice în Delta Dunării. Mormintele cu ocru de la Chilia-Veche. Peuce 11, 49-87.

Vella, C., Fleury, T.J., Raccasi, G., Provansal, M., Sabatier, F., Bourcier, M., 2005. Evolution of the Rhone delta plain in the Holocene. Marine Geology 222, 235-265.

Yanko-Hombach, V.V., 2007. Controversy over Noah's flood in the Black Sea: geological and foraminiferal evidence from the shelf. In: Yanko-Hombach, V., Gilbert, A.S., Panin, N., Dolukhanov, P. (Eds.), The Black Sea Flood Question: Changes in Coastline, Climate, and Human Settlement. Springer, Dordrecht, The Netherlands, pp. 149-204. 